\section{Simulated drift of dicamba: effect on the physiological quality of soybean seeds}

\author{
Estevam Matheus $\operatorname{Costa}^{1^{*}}$, Jacson Zuchi ${ }^{1} \mathbb{D}$, Matheus Vinícius Abadia \\ Ventura $^{1}$, Leandro Spíndola Pereira ${ }^{1}(\mathbb{D})$, Geovani Borges Caetano ${ }^{1}$, \\ Adriano Jakelaitis ${ }^{1}$ i
}

ABSTRACT: The release of soybean varieties resistant to dicamba herbicide leads to the possibility of dicamba herbicide drift into soybean seed production fields and reduction in the physiological quality of soybean seeds. The aim of this study was to evaluate the physiological quality of soybean seeds as a function of the application of reduced rates of dicamba in two phenological phases. A randomized block experimental design was used, with four replications. The $4 \times 2+1$ factorial arrangement consisted of four reduced rates $\left(0.028,0.28,2.8\right.$ and $\left.28 \mathrm{~g} \mathrm{ha}^{-1}\right)$ of dicamba applied in the $\mathrm{V}_{4}$ and $\mathrm{R}_{2}$ stages $+\mathrm{a}$ control. The physiological quality of the seeds was evaluated after harvest and at six months after storage at $20{ }^{\circ} \mathrm{C}$. At the rate of $28 \mathrm{~g} \cdot \mathrm{ha}^{-1}$ of dicamba applied in the $\mathrm{V}_{4}$ and $\mathrm{R}_{2}$ stages, seed germination declined by $15 \%$ and $42 \%$, respectively. After storage, seeds under the $28 \mathrm{~g}^{\text {. ha }}{ }^{-1}$ dicamba treatment had $64 \%$ lower germination compared to the lowest application rate evaluated, and electrical conductivity doubled in relation to the control. The physiological quality of soybean seeds declines under these reduced rates of dicamba applied in the $\mathrm{V}_{4}$ and $R_{2}$ stages, both before and after storage.

Index terms: application times, germination, Glycine max, reduced application rates, storage.

\section{Deriva simulada de dicamba: efeitos sobre a qualidade fisiológica de sementes de soja}

RESUMO: Com a inserção de variedades de soja resistentes ao herbicida dicamba, surge a possibilidade de deriva deste herbicida em campos de produção e a ocorrência de redução na qualidade fisiológica das sementes. Objetivou-se avaliar a qualidade fisiológica das sementes de soja em função da aplicação de subdoses de dicamba em duas fases fenológicas. 0 delineamento foi em blocos casualizados, com quatro repetições. $O$ esquema fatorial $4 \times 2+$ 1 composto por quatro doses $\left(0,028,0,28,2,8\right.$ e $\left.28 \mathrm{~g}_{\text {.ha }}{ }^{-1}\right)$ de dicamba aplicados em $\mathrm{V}_{4}$ e $\mathrm{R}_{2}+$ testemunha. A qualidade fisiológica das sementes foi avaliada após a colheita e aos seis meses após armazenadas a $20^{\circ} \mathrm{C}$. Na dose de $28 \mathrm{~g}$.ha ${ }^{-1}$ de dicamba aplicados em $\mathrm{V}_{4}$ e $\mathrm{R}_{2^{\prime}}$ as sementes apresentaram redução da germinação em 15 e $42 \%$, respectivamente. Após o armazenamento, as sementes do tratamento com 28 g.ha ${ }^{-1}$ de dicamba apresentaram germinação $64 \%$ menor se comparado à menor dose avaliada e a condutividade elétrica duplicou em relação à testemunha. As sementes de soja têm sua qualidade fisiológica reduzida por subdoses de dicamba aplicadas nos estádios $V_{4}$ e $R_{2}$ tanto antes quanto após o armazenamento.

Termos para indexação: armazenamento, épocas de aplicação, germinação, Glycine max, subdoses.
Journal of Seed Science, v.42, e202042014, 2020

http://dx.doi.org/10.1590/2317$1545 v 42224236$
$*$ Corresponding author
E-mail: estevammcosta@yahoo.com.br

Received: 5/20/2019. Accepted: 10/25/2019.

${ }^{1}$ Instituto Federal Goiano, campus Rio Verde, 75901-970 - Rio Verde, Goiás, Brasil. 


\section{INTRODUCTION}

The development of soybean varieties with tolerance to hormonal herbicides, such as 2,4-D and dicamba, has been adopted as part of a program for management of eudicot weeds that are tolerant or resistant to the herbicides commonly used in the crop, such as glyphosate (Silva et al., 2018). However, when this technology is not used within the principles of integrated weed management, it may lead to an increase in the application of these hybrids in soybean production areas (Solomon and Bradley, 2014).

The quality of soybean seeds can be affected, in accordance with the genotype, the edaphic and climatic conditions, and biotic factors, and quality may deteriorate during storage under inadequate temperature and relative humidity conditions (Zuchi et al., 2013). Though deterioration occurs, it can be retarded, depending on the storage conditions and on the seed characteristics (Cardoso et al., 2012). Deterioration reduces the quality, viability, and vigor of seeds, due to aging or to the effects of adverse environmental factors (Siadat et al., 2012).

Auxinic herbicides act in a similar way to indole-3-acetic acid (IAA); however, they are more persistent and active than IAA, damaging sensitive crops even at very low concentrations (Oliveira-Júnior, 2011), as occurs in cases of spray drift, which is deviation of particles applied in a certain area to an adjacent area, and contamination from spray equipment. The application of endogenous auxins on soybean seeds negatively regulates gibberellin biosynthesis and leads to an increase in the concentration of abscisic acid, resulting in secondary dormancy and reducing germination through delay in primary root emergence (Shuai et al., 2017). In addition, these hormones regulate fruit and seed formation (Ren and Wang, 2016).

Hormonal herbicide drift can lead to injuries in parent plants, reduce yield, and affect the physiological quality of soybean seeds. The application of auxinic herbicides in the vegetative and reproductive stages of soybean reduces seed quality (Silva et al., 2018). Dicamba applied in the reproductive stage of the soybean crop affects the seed and, consequently, the plants of the following crop season (Barber et al., 2016; Miller and Norsworthy, 2018). Application of dicamba reduced the germination and vigor of soybean seeds (Silva et al., 2018). Robinson et al. (2013) observed changes in the composition of seeds, with reductions in lipid contents in soybean seeds when the plants were treated with dicamba in the vegetative and reproductive stages, while the protein content decreased when dicamba applications occurred in the $\mathrm{V}_{2}$ and $\mathrm{V}_{5}$ stages and increased under applications made in $\mathrm{R}_{2}$.

The aim of this study was to evaluate the physiological quality of soybean seeds as a function of application of reduced rates of dicamba in two phenological phases $\left(V_{4}\right.$ and $\left.R_{2}\right)$ of the crop.

\section{MATERIAL AND METHODS}

The trial was set up in Rio Verde, GO, at $17^{\circ} 48^{\prime} 67^{\prime \prime} \mathrm{S}$ and $50^{\circ} 54^{\prime} 18^{\prime \prime} \mathrm{W}$, and altitude of $720 \mathrm{~m}$. Climate in the region according to the Köppen-Geiger climate classification is Aw (tropical), with rainfall in October to April and a dry period from May to September. Soil in the location, of clayey texture (64.5\%), had the following traits at the depth of 0 to $20 \mathrm{~cm}: \mathrm{pH}\left(\mathrm{CaCl}_{2}\right)$ of 5.4 , organic matter content of $3.9 \%$, and a base saturation index of $71 \%$. During the period of conducting the experiment in the field, the rainfall registered was 147, 244, 267, 136, and $20 \mathrm{~mm}$, while the mean temperature was $25,24.4,24.8,24.9$, and $26.3^{\circ} \mathrm{C}$ for the months of November and December (2017) and January, February, and March (2018), respectively.

For the field experiment, a randomized block experimental design was used, with four replications. The factorial arrangement adopted was $4 \times 2+1$, with four reduced application rates $(0.028,0.28,2.8$ and $28 \mathrm{~g}$ of acid equivalent per hectare) of dicamba applied in two phenological stages of the soybean crop $\left(V_{4}\right.$ and $\left.R_{2}\right)+$ an additional treatment without application of the herbicide. The $V_{4}$ stage is characterized by development of the second trifoliate leaf on the main stem, and the $R_{2}$ stage is characterized by full flowering of the soybean plants. The plots were $25.2 \mathrm{~m}^{2}$, with eight rows of $7 \mathrm{~m}$ length, spaced at $0.45 \mathrm{~m}$. The area used for data collection was the five central meters of five center rows of each plot. 
The soybean variety used was ADV 4672 IPRO and was sown mechanically in a no-till system, with eighteen seeds per linear meter. Seed treatment, crop management practices, and plant health management were carried out in accordance with EMBRAPA (2013). Dicamba drift was simulated using a backpack sprayer under $\mathrm{CO}_{2}$ pressure, regulated

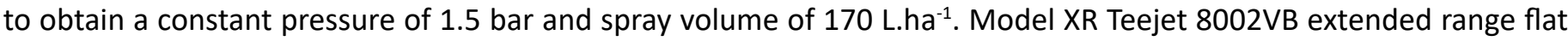
spray tips were used.

Harvest was performed manually in the R8 stage (full maturity - $95 \%$ of the pods with mature color), and plants were mechanically threshed. After threshing, the seeds were manually cleaned and then dried in a forced-air circulation oven at a temperature of $25{ }^{\circ} \mathrm{C}$ until the seeds reached $10.5 \%$ moisture; the drying process took approximately ten hours. After drying, part of the seeds was stored in a BOD type chamber in polyethylene bags at a constant temperature of $20{ }^{\circ} \mathrm{C}$ for six months. Relative humidity $(\mathrm{RH})$ and temperature were recorded by a digital data logger (precision: $0.1{ }^{\circ} \mathrm{C} ; 5.0 \% \mathrm{RH}$ ).

The seeds were placed in BOD under controlled conditions for a period of six months. Moisture content was not affected; the moisture level was $9.92 \%$ before storage and $10.64 \%$ after six months of storage.

The traits described below were evaluated through duplicate samples of fifty seeds for each one of four replications, following the same experimental design used in the field:

Moisture content: determined using a sample with weight from 4.5 to $5 \mathrm{~g}$ by the laboratory oven method at 105 $\pm 3^{\circ} \mathrm{C}$ for 24 hours (Brasil, 2009).

Electrical conductivity (EC): Each replication of fifty soybean seeds was first weighed (precision of $0.001 \mathrm{~g}$ ), recording the weight for use in calculations, and then placed to soak in plastic cups (200 mL) containing $75 \mathrm{~mL}$ of deionized water and kept at $25^{\circ} \mathrm{C}$ for $24 \mathrm{~h}$ (Hampton and Tekrony, 1995; Vieira and Krzyzanowski, 1999). At the end of the soaking period, electrical conductivity was read, using a digital conductivity meter Technal, model TEC-4MP. Results were expressed in micro Siemens per centimeter per gram $\left(\mu \mathrm{S} \mathrm{cm} \mathrm{cm}^{-1} \cdot \mathrm{g}^{-1}\right)$.

Germination $(G)$ : Before sowing, seeds were treated with carbendazim + thiram at the rate of 0.3 and $0.7 \mathrm{~g}$ of active ingredient per kilogram of seed. The seeds were then placed to germinate in a germination paper substrate (Germitest ${ }^{\circ}$ ) moistened with water in the amount of 2.5 times the weight of the dry Germitest ${ }^{\circ}$ paper, at $25^{\circ} \mathrm{C}$. Evaluations were made at five days (first germination count) and eight days after sowing, and results were expressed in percentage of normal seedlings (Brasil, 2009).

First germination count (FGC): Counting and recording the number of normal seedlings, performed on the fifth day after setting up the germination test (Brasil, 2009).

Emergence speed index (ESI) and emergence (E): Tests were performed through sowing in seed beds containing sand substrate, with four replications of fifty seeds. Sowing depth was $2.5 \mathrm{~cm}$. The emerged seedlings were counted daily up to stabilization of emergence. Seedlings with cotyledons in the horizontal position were considered as emerged. Results of the emergence speed index were calculated according to Maguire (1962).

Accelerated aging (AA): "gerbox" boxes were used, containing $40 \mathrm{~mL}$ of distilled water. Two hundred seeds of each treatment were distributed on an internal metallic screen in each gerbox, and the gerboxes were incubated at $41^{\circ} \mathrm{C}$ for 48 hours (Marcos-Filho, 1999). After that period, the germination test was conducted on the seeds, under the conditions described above.

Seedling length (SL): ten seedlings coming from the germination test of each experimental unit were used. Evaluation was made on the eighth day after setting up the germination test, selecting seedlings classified as normal in the germination test of the seeds that did not pass through the accelerated aging process. Total seedling length was determined from the tip of the main root to the cotyledonary node (connection of cotyledon to the stem) with the assistance of a millimeter ruler at eight days after sowing (Krzyzanowiski et al., 1999).

The Shapiro-Wilk normality test $(p \leq 0.05)$ was used on the results, and analysis of variance $(p \leq 0.05)$ on those meeting the presuppositions. When significant, the results were subjected to the Dunnett test for contrasts of the treatments with the non-treated control, and to Tukey's test $(p \leq 0.05)$ for contrast of the mean values between reduced application rates and herbicide application times. Data regarding germination from the accelerated aging test 
were transformed into arcsin of the square root of $x / 100$, in which $x$ was the value in percentage. Analyses were made through the software ASSISTAT (Silva and Azevedo, 2002).

\section{RESULTS AND DISCUSSION}

There were significant interactions between the reduced application rates of dicamba $(0.028,0.28,2.8$ and 28 g.ha-1 ${ }^{-1}$ and the phenological stages $\left(V_{4}\right.$ and $R_{2}$ - in which the herbicide was applied) on germination percentage (G). There was also significant interaction between the factors and the control treatment in the evaluations made soon after harvest (Table 1). Seed germination evaluated after soybean harvest was lowest for the highest application rate of dicamba, especially when applied in the $\mathrm{R}_{2}$ stage. The application rate of $28 \mathrm{~g}$.ha-1, i.e., $5.8 \%$ of the application rate recommended on the label of Dicamax, was enough to reduce germination by $14 \%$ in $V_{4}$ and $39 \%$ in $R_{2}$ in relation to the control (Table 1).

Table 1. Germination percentage $(G)$ and first germination count $(F G C)$ of soybean seeds under reduced rates of dicamba applied in the $V_{4}$ and $R_{2}$ stages in evaluations made after crop harvest and after six months of storage.

\begin{tabular}{|c|c|c|c|c|c|c|}
\hline \multirow{3}{*}{$\begin{array}{l}\text { Reduced application rate } \\
\qquad\left(\mathrm{g} \text { a.e. } \mathrm{ha}^{-1}\right)\end{array}$} & \multicolumn{2}{|c|}{ G (\%) } & \multirow{2}{*}{ Mean } & \multicolumn{2}{|c|}{ FGC (\%) } & \multirow[t]{2}{*}{ Mean } \\
\hline & $V_{4}$ & $\mathrm{R}_{2}$ & & $\mathrm{~V}_{4}$ & $\mathrm{R}_{2}$ & \\
\hline & \multicolumn{6}{|c|}{ Seeds obtained after harvest } \\
\hline 0.028 & $84 \mathrm{abA}$ & $90 \mathrm{aA}$ & 87 & 92 & 97 & 94 a \\
\hline 0.28 & $93 \mathrm{aA}$ & $94 \mathrm{aA}$ & 93 & 94 & 97 & 95 a \\
\hline 2.8 & $90 \mathrm{aA}$ & $92 \mathrm{aA}$ & 91 & 93 & 96 & $94 \mathrm{a}$ \\
\hline 28 & $77 \mathrm{bA}^{(-)}$ & $52 \mathrm{bB}^{(-)}$ & 64 & $74^{(-)}$ & $67^{(-)}$ & $71 b$ \\
\hline Mean & 86 & 82 & - & 88 & 89 & - \\
\hline Control & \multicolumn{3}{|c|}{91} & \multicolumn{3}{|c|}{97} \\
\hline CV (\%) & \multicolumn{2}{|c|}{6.84} & - & \multicolumn{2}{|c|}{5.83} & - \\
\hline $\mathrm{F}_{\mathrm{A}}$ & \multicolumn{3}{|c|}{$42.6077^{*}$} & \multicolumn{3}{|c|}{$42.8049 *$} \\
\hline $\mathrm{F}_{\mathrm{B}}$ & \multicolumn{3}{|c|}{$3.8257^{\mathrm{ns}}$} & \multicolumn{3}{|c|}{$0.2257^{\mathrm{ns}}$} \\
\hline$F_{A \times B}$ & \multicolumn{3}{|c|}{$11.3549 *$} & \multicolumn{3}{|c|}{$2.3962^{\mathrm{ns}}$} \\
\hline \multirow{2}{*}{$\mathrm{F}_{\text {TreatxAddit. }}$} & & $4.6642 *$ & & & $6.7670^{*}$ & \\
\hline & \multicolumn{6}{|c|}{ Seeds stored for six months after storage } \\
\hline 0.028 & 77 & 83 & $80 \mathrm{a}$ & 91 & 92 & $92 \mathrm{a}$ \\
\hline 0.28 & 87 & 82 & $84 \mathrm{a}$ & 95 & 91 & $93 \mathrm{a}$ \\
\hline 2.8 & 82 & 70 & $76 a$ & 93 & 80 & $87 a$ \\
\hline 28 & 34 & 23 & $29 \mathrm{~b}$ & 63 & 71 & $67 \mathrm{~b}$ \\
\hline Mean & 70 & 64 & - & 85 & 84 & - \\
\hline Control & \multicolumn{3}{|c|}{62} & \multicolumn{3}{|c|}{93} \\
\hline CV (\%) & & & - & & & - \\
\hline $\mathrm{F}_{\mathrm{A}}$ & \multicolumn{3}{|c|}{$21.2300^{*}$} & \multicolumn{3}{|c|}{$8.3836^{*}$} \\
\hline $\mathrm{F}_{\mathrm{B}}$ & \multicolumn{3}{|c|}{$0.9986^{\mathrm{ns}}$} & \multicolumn{3}{|c|}{$0.1970^{\text {ns }}$} \\
\hline$F_{A \times B}$ & \multicolumn{3}{|c|}{$0.5459^{\text {ns }}$} & \multicolumn{3}{|c|}{$1.0906^{\mathrm{ns}}$} \\
\hline $\mathrm{F}_{\text {TreatxAddit. }}$ & \multicolumn{3}{|c|}{$0.3775^{\mathrm{ns}}$} & \multicolumn{3}{|c|}{$1.5939^{\text {ns }}$} \\
\hline
\end{tabular}

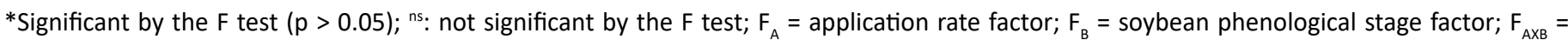
interaction; $F_{\text {Treatxaddit. }}=$ treatments $x$ additional. Mean values followed by different lowercase letters in the columns or different uppercase letters in the rows differ from each other by Tukey's test $(p<0.05)$. Mean values followed by $(-)$ were less than the control by the Dunnett test $(p<0.05)$. 
Dicamba applied at flowering reduced germination of soybean seeds (Wax et al., 1969). Use of dicamba in the $V_{5}$ stage reduced soybean seed germination an average of $14 \%$ (Silva et al., 2018). Miller and Norsworthy (2018) observed reduction of $5 \%$ in germination of soybean seeds treated with $28 \mathrm{~g}$.ha ${ }^{-1}$ of dicamba applied in $\mathrm{R}_{2^{\prime}}$ whereas at the application rate of $3.5 \mathrm{~g}$.ha ${ }^{-1}$, there was no reduction. These authors also observed reduction of $69 \%$ in germination

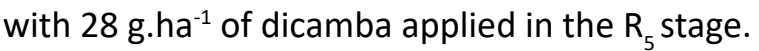

In the stored seeds, no interaction was observed between the reduced application rates and the times of application of the herbicide for seed germination percentage (Table 1). Nevertheless, a significant effect was found for the reduced application rates, which decreased the germination percentage at the highest rate applied. The rate of $28 \mathrm{~g} \cdot \mathrm{ha}^{-1}$ of dicamba reduced germination by $64 \%$ in relation to the lowest rate tested (Table 1). Germination of the treatments with the reduced application rate of $28 \mathrm{~g} \cdot \mathrm{ha}^{-1}$ of dicamba did not achieve $80 \%$ germination, the minimum required for sale of soybean seeds in Brazil (Brasil, 2009).

In relation to FGC of the seeds after soybean harvest, no effect of the interaction between the reduced application rate and herbicide application time factors was observed, only the effect of the reduced application rates, with reduction of $24.5 \%$ at the rate of $28 \mathrm{~g} . \mathrm{ha}^{-1}$ of dicamba in relation to the lowest rate applied (Table 1). For the reduced application

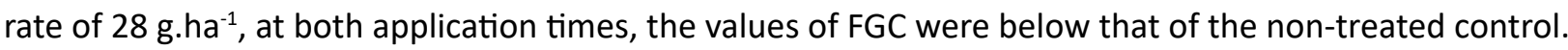

After storage, there was no significant interaction between the factors; nevertheless, the reduced application rates

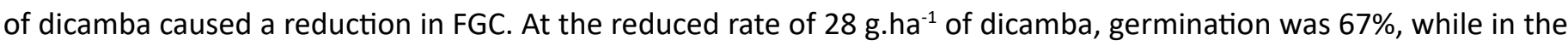
other treatments, the FGC was between $93 \%$ and $87 \%$ (Table 1). There was reduction of $19 \%$ in FGC due to applications of 29.8 g.ha-1 of dicamba in $R_{2}$ and of $8 \%$ for applications in $V_{5}$ (Silva et al., 2018), showing that the reduced application rates of dicamba lowered seed vigor in a more expressive way in applications in $R_{2}$. Thus, drift events that occur in that stage make production of soybean seeds inviable.

In the accelerated aging test of the seeds after soybean harvest, no significant interaction was observed between the reduced rates of dicamba factor and plant stage factor, but only the effect of application of reduced rates was observed, with the lowest values in the AA test at the application rate of $28 \mathrm{~g} \mathrm{ha}^{-1}$ of dicamba (Table 2). Considering the effects of treatments in relation to the control, germination for the reduced application rate of $28 \mathrm{~g}$. ha ${ }^{-1}$ of dicamba applied in $\mathrm{V}_{4}$ and in $\mathrm{R}_{2}$ decreased soybean seed germination by $38 \%$ and $40 \%$, respectively.

After storage, there was no significant interaction between the reduced application rates of dicamba and the plant stages at dicamba application. Nevertheless, there was a significant effect from the reduced application rates of dicamba; the germination percentage in accelerated aging was $5 \%$ at the highest application rate evaluated, whereas in the other reduced application rates, germination ranged from 30\% to 38\% (Table 2). These data corroborate those obtained by Miller and Norsworthy (2018), who observed reductions of $18 \%$ and $45 \%$ in seed germination in the accelerated aging test in the treatments with $28 \mathrm{~g}$.ha-1 of dicamba in the $R_{2}$ and $R_{3}$ stages, respectively. For the reduced application rate of $3.5 \mathrm{~g}$ ha $^{-1}$ of dicamba, these same authors did not observe reductions as a result of the applications made in the $R_{1}, R_{2}$, and $R_{3}$ stages.

Accumulation of dicamba can reduce seed germination (Auch and Arnold, 1978). Dicamba that is not metabolized in the plant is transported to the seed during the stages of seed filling (Thompson and Egli, 1973). Thus, reduction in germination due to the reduced application rates of dicamba tested indicates that the soybean seeds were not able to metabolize this herbicide during the storage period, which reduced germination.

In length of seedlings from seeds after soybean harvest and from stored seeds, there was no interaction between the reduced application rates of dicamba and the plant stages at which application was made; nevertheless, seedling length declined as a function of the reduced application rates of dicamba (Table 2). In the newly harvested seeds, length declined by around $43 \%$ at the reduced application rate of $28 \mathrm{~g} \cdot \mathrm{ha}^{-1}$ compared to the treatment with $2.8 \mathrm{~g} \cdot \mathrm{ha}^{-1}$ and the treatment of $0.28 \mathrm{~g} \cdot$ ha $^{1}$ (Table 2).

After storage, seedling length declined by $33 \%$ at the application rate of $28{\mathrm{~g} . h a^{-1}}^{-1}$ in relation to the application rate of $0.28 \mathrm{~g}$.ha ${ }^{-1}$. Seedling length was also less when dicamba had been applied in $R_{2}$. In that stage, there was reduction 
of $2.3 \mathrm{~cm}$ compared to the $\mathrm{V}_{4}$ stage. The study in reference to length and dry matter of seedlings or of their parts is effective in detecting subtle differences in seed vigor (Vanzolini et al., 2007). The reduced application rates of dicamba aiming to simulate drift reduces the physiological quality of soybean seeds, affecting their vigor, since there was lower transfer of nutrients from the seed to the seedling in the treatments with $28 \mathrm{~g}$ a.e ha-1.

In the emergence speed index (ESI) of the newly harvested seeds, there was no significant interaction between the factors of reduced dicamba application rate and the stage of the plant at the time of dicamba application. Nevertheless, in the seeds evaluated after six months of storage, there was significant interaction between the factors tested. The ESI was lower in the seeds under the higher application rate of dicamba, both in the newly harvested seeds and in the stored seeds (Table 3). Slow, reduced, or uneven emergence can result in gaps in stand, delay in development, problems for weed control, and interference in plant characteristics related to harvest (Marcos-Filho, 2013).

The ESI of the stored seeds in the treatments with the application rate of $28 \mathrm{~g}$.ha-1 of dicamba, applied in $\mathrm{V}_{4}$ and $\mathrm{R}_{2}$ was 3.1 and 6.9, respectively. At the rates lower than this, the ESI ranged from 8.3 to 10.2 , with reduction of up to $70 \%$

Table 2. Accelerated aging (AA) and seedling length (SL) of soybean seeds under reduced rates of dicamba applied in the $V_{4}$ and $R_{2}$ stages in evaluations made after crop harvest and after six months of storage.

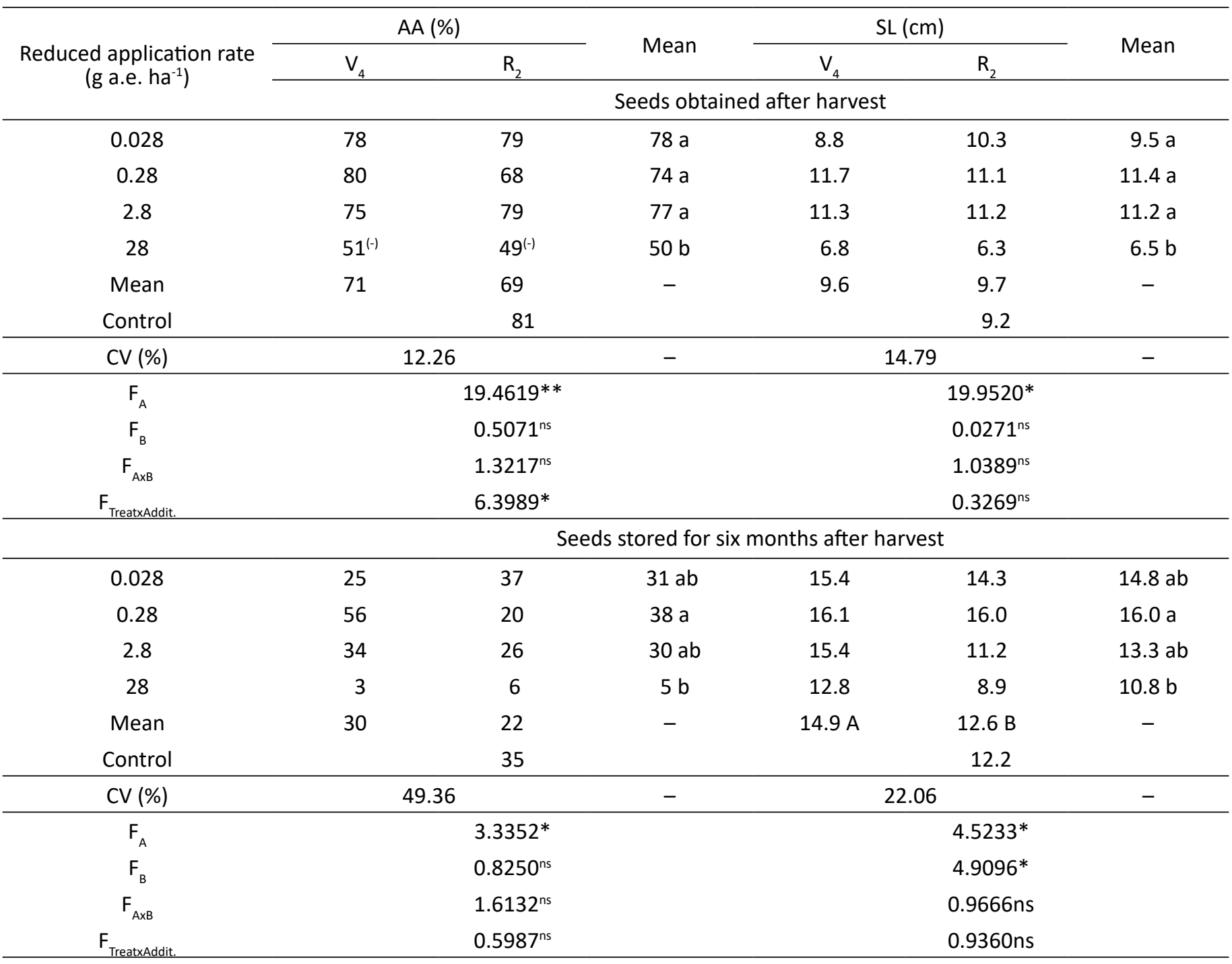

*Significant by the $F$ test $(p>0.05)$; ${ }^{\text {ss: }}$ not significant by the $F$ test; $F_{A}=$ application rate factor; $F_{B}=$ soybean phenological stage factor; $F_{A X B}=$ interaction; $F_{\text {Treatxaddit }}=$ treatments $x$ additional. Mean values followed by different lowercase letters in the columns or different uppercase letters in the rows differ from each other by Tukey's test $(p<0.05)$. Mean values followed by $(-)$ were less than the control by the Dunnett test $(p<0.05)$. 
in the ESI (Table 3). Speed of emergence is fundamental for rapid establishment of seedlings. Thus, greater ESI results in better performance and greater capacity for resisting stresses that may interfere in the growth and development of the plant (Dan et al., 2010). The occurrence of dicamba drift at the reduced rate of $28 \mathrm{~g}$.ha ${ }^{-1}, 5.8 \%$ of the rate recommended on the label, in a soybean seed production field can result in damage to the seeds produced from the soybean plants that were contaminated, since these reduced rates of dicamba decrease the vigor of soybean seeds.

The emergence percentage in sand after harvest of the seeds was not affected by interaction between application rates and the time periods of application, whereas in the stored seeds, there was significant interaction between these factors (Table 3). In the seeds evaluated after harvest, the emergence percentage was lower at the application rate of $28 \mathrm{~g}$.ha ${ }^{-1}$ of dicamba, with $78 \%$ emergence, regardless of the phenological stage in which it was applied. After storage, at the highest application rate of dicamba $\left(28 \mathrm{~g} \cdot \mathrm{ha}^{-1}\right)$, there was greater reduction when application was made in $R_{2}$ than in $\mathrm{V}_{4}$ (Table 3). Auch and Arnold (1978) observed reductions in soybean seedling emergence due to the treatment with 11 and 56 g.ha ${ }^{-1}$ of dicamba.

Table 3. Emergence speed index (ESI) and emergence percentage (E) of soybean seeds under reduced rates of dicamba applied in the $V_{4}$ and $R_{2}$ stages in evaluations made after crop harvest and after six months of storage.

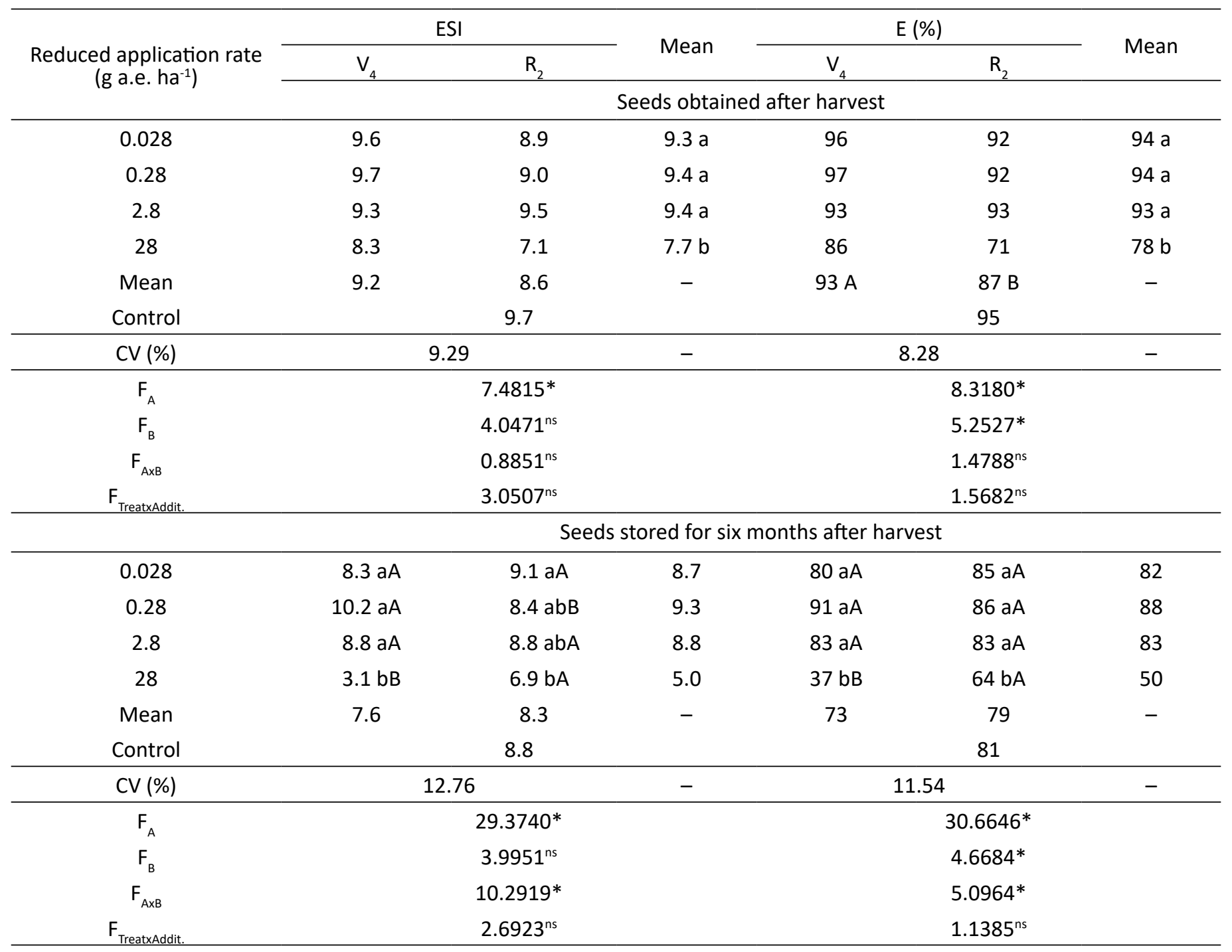

*Significant by the $F$ test $(p>0.05)$; ${ }^{\text {ss: }}$ not significant by the $F$ test; $F_{A}=$ application rate factor; $F_{B}=$ soybean phenological stage factor; $F_{A X B}=$ interaction; $F_{\text {Treatxaddit. }}=$ treatments $x$ additional. Mean values followed by different lowercase letters in the columns or different uppercase letters in the rows differ from each other by Tukey's test $(p<0.05)$. 
Severe reductions in the speed and percentage of seedling emergence generally result in problems during plant development (Marcos-Filho, 2013), such as reduction in the ability of the crop to compete with weeds and more susceptibility to attack from pathogens. Therefore, dicamba drift can potentially reduce crop yield in the event of use of seeds that have been contaminated by this herbicide, since reduction in seed physiological potential indirectly affects agricultural production, due to its reflections on initial plant stand (Marcos-Filho, 2005; Marcos-Filho, 2013).

In electrical conductivity, there was significant interaction between the application rate and the time period of application in the seeds evaluated after harvest, whereas for the stored seeds, there was no significant interaction (Table 4). After harvest, electrical conductivity of the seeds was higher in the treatments with $28 \mathrm{~g}$ ha $^{-1}$ of dicamba applied at $\mathrm{R}_{2}$. At that application rate, electrical conductivity was two times greater than in the control treatment and higher than in the other treatments.

After storage, electrical conductivity of the seeds coming from soybean plants treated with $28 \mathrm{~g}$.ha ${ }^{-1}$ of dicamba applied in $R_{2}$ was double the electrical conductivity values of the control treatment, an effect similar to that obtained

Table 4. Electrical conductivity (EC) of soybean seeds under reduced rates of dicamba applied in the $V_{4}$ and $R_{2}$ stages in evaluations made after crop harvest and after six months of storage.

\begin{tabular}{|c|c|c|c|}
\hline \multirow{3}{*}{$\begin{array}{l}\text { Reduced application rate } \\
\qquad\left(\mathrm{g} \text { a.e. } \text { ha }^{-1}\right)\end{array}$} & \multicolumn{2}{|c|}{$\mathrm{EC}\left(\mu \mathrm{S} \mathrm{cm} \mathrm{cm}^{-1} \mathrm{~g}^{-1}\right)$} & \multirow{2}{*}{ Mean } \\
\hline & $\mathrm{V}_{4}$ & $\mathrm{R}_{2}$ & \\
\hline & \multicolumn{3}{|c|}{ Seeds obtained after harvest } \\
\hline 0.028 & $81 \mathrm{aA}$ & $70 \mathrm{aA}$ & 76 \\
\hline 0.28 & $73 \mathrm{aA}$ & 73 aA & 73 \\
\hline 2.8 & $86 \mathrm{aA}$ & $80 \mathrm{aA}$ & 83 \\
\hline 28 & $92 \mathrm{aA}$ & $140 \mathrm{bB}^{(-)}$ & 116 \\
\hline Mean & 83 & 91 & - \\
\hline Control & & 71 & \\
\hline CV (\%) & & & - \\
\hline $\mathrm{F}_{\mathrm{A}}$ & & $20.3090 *$ & \\
\hline $\mathrm{F}_{\mathrm{B}}$ & & $3.1322^{\text {ns }}$ & \\
\hline $\mathrm{F}_{\mathrm{AxB}}$ & & $9.1157^{*}$ & \\
\hline \multirow[t]{2}{*}{$\mathrm{F}_{\text {TreatxAddit. }}$} & & $5.4284 *$ & \\
\hline & \multicolumn{3}{|c|}{ Seeds stored for six months after harvest } \\
\hline 0.028 & 111 & 121 & $116 \mathrm{a}$ \\
\hline 0.28 & 106 & 115 & $110 \mathrm{a}$ \\
\hline 2.8 & 124 & 121 & $123 \mathrm{a}$ \\
\hline 28 & 143 & $196^{(-)}$ & $169 \mathrm{~b}$ \\
\hline Mean & 121 & 138 & - \\
\hline Control & & 95 & \\
\hline CV (\%) & & & - \\
\hline $\mathrm{F}_{\mathrm{A}}$ & & 7.7299* & \\
\hline $\mathrm{F}_{\mathrm{B}}$ & & $3.2206^{\mathrm{ns}}$ & \\
\hline $\mathrm{F}_{\mathrm{AxB}}$ & & $1.5916^{\mathrm{ns}}$ & \\
\hline $\mathrm{F}_{\text {TreatxAddit. }}$ & & $5.5371^{*}$ & \\
\hline
\end{tabular}

*Significant by the $F$ test $(p>0.05)$; ${ }^{\text {ns: }}$ not significant by the $F$ test; $F_{A}=$ application rate factor; $F_{B}=$ soybean phenological stage factor; $F_{A X B}=$ interaction; $F_{\text {TreatxAddit. }}=$ treatments $x$ additional. Mean values followed by different lowercase letters in the columns or different uppercase letters in the rows differ from each other by Tukey's test $(p<0.05)$. Mean values followed by $(-)$ were less than the control by the Dunnett test $(p<0.05)$. 
in the newly harvested seeds. After storage, electrical conductivity of the control was $95.4 \mu \mathrm{S} \mathrm{cm}^{-1} \cdot \mathrm{g}^{-1}$, and at the application rate of $28 \mathrm{~g}$.ha ${ }^{-1}$, it reached 142.8 and $195.9 \mu \mathrm{S} \mathrm{m}^{-1} \cdot \mathrm{g}^{-1}$ for application made in the $\mathrm{V}_{4}$ and $\mathrm{R}_{2}$ stages, respectively (Table 4). For high vigor seeds, electrical conductivity should be between 70 and $80 \mu \mathrm{sm}^{-1} \cdot \mathrm{g}^{-1}$ (Vieira and Krzyzanowiski, 1999).

The increase in electrical conductivity shows that there was damage in the cell membrane system (Marcos-Filho et al., 1987). This damage results in leaching of sugars, amino acids, electrolytes, and other water soluble substances (Heydecker, 1974), leading to reduction in the vigor of seeds from plants reached by dicamba drift. During deterioration, the first events that occur are disorganization and loss of control of the permeability of seed membranes, and this situation results in reduced germination and in embryo death (Delouche and Baskin, 1973).

\section{CONCLUSIONS}

Reduced rates of dicamba applied in the $\mathrm{V}_{4}$ and $\mathrm{R}_{2}$ stages of the soybean crop reduce seed physiological quality after crop harvest and after six months of storage. The application rate of $28 \mathrm{~g} \cdot \mathrm{ha}^{-1}$ more expressively reduces germination, first germination count, emergence speed index and emergence percentage, seedling length, and electrical conductivity of soybean seeds, especially after a period of storage.

\section{ACKNOWLEDGMENTS}

This study was conducted with the support of the Coordenação de Aperfeiçoamento de Pessoal de Nivel Superior (CAPES) under funding code 001 and of the Instituto Federal Goiano, Rio Verde campus.

\section{REFERENCES}

AUCH, D.E.; ARNOLD, W.E. Dicamba use and injury on soybeans (Glycine max) in South Dakota. Weed Science, v.26, n.5, p.471-475, 1978. https://www.jstor.org/stable/4042904

BARBER, L.T.; NORSWORTHY, J.K.; MCCOWN, M.S. Dicamba effects on soybean plants and their progeny. Arkansas Soybean Research Studies 2014, p.147-149, 2016. https://scholarworks.uark.edu/cgi/viewcontent.cgi?article=1022\&context=aaesser\#page=150

BRASIL. Ministério da Agricultura, Pecuária e Abastecimento. Regras para análise de sementes. Ministério da Agricultura, Pecuária e Abastecimento. Secretaria de Defesa Agropecuária. Brasília: MAPA/ACS, 2009. 395p. http:// www.agricultura.gov.br/arq_editor/ file/2946_regras_analise_sementes.pdf

CARDOSO, R.B.; BINOTTI, F.F.S.; CARDOSO, E.D. Potencial fisiológico de sementes de crambe em função de embalagens e armazenamento. Pesquisa Agropecuária Tropical, v.42, n.3, p.272-278, 2012. http://dx.doi.org/10.1590/S1983-40632012000300006

DAN, L.G.M.; DAN, H.A.; BARROSO, A.L.L.; BRACCINI, A.L. Qualidade fisiológica de sementes de soja tratadas com inseticidas sob efeito do armazenamento. Revista Brasileira de Sementes, v.32, n.2, p.131-139, 2010. http://dx.doi.org/10.1590/s010131222010000200016

DELOUCHE, J.C.; BASKIN, C.C. Accelerated aging techniques for predicting the relative storability of seed lots. Seed Science and Technology, v.1, p.427-452, 1973. https://ir.library.msstate.edu/bitstream/handle/11668/13316/F-4.pdf?sequence=1\&isAllowed=y

EMBRAPA. Tecnologias de produção de soja - região central do Brasil 2014. Londrina: EMBRAPA Soja, 2013. 265p.

HEYDECKER, W. Vigour. In: ROBERTS, G.H. (ed.) Viability of seeds. London: Chapman and Hall, 1974. p.209-520.

KRZYZANOWISKI, F.C; VIEIRA, R.D; FRANÇA-NETO, J.B. (ed). Vigor de sementes: conceitos e testes. Londrina: ABRATES, 1999.

MAGUIRE, J.D. Speed of germination: aid in selection and evaluation for seedling emergence and vigor. Crop Science, v.2, n.2, p.176177, 1962. http://dx.doi.org/10.2135/cropsci1962.0011183X000200020033x

MARCOS-FILHO, J. Teste de envelhecimento acelerado. In: KRZYZANOWSKI, F.C.; VIEIRA, R.D.; FRANÇA-NETO, J.B. (ed.). Vigor de sementes: conceitos e testes. Londrina: ABRATES, 1999. p.1-24. 
MARCOS-FILHO, J. Importância do potencial fisiológico da semente de soja. Informativo ABRATES, v.23, n.1, p.21-23, 2013. https:// www.abrates.org.br/img/informations/950ff7fa-c03a-4960-a520-f6cb0870babe_IA\%20vol.23\%20n.1.pdf

MARCOS-FILHO, J.; CICERO, S.M.; SILVA, W.R. Avaliação da qualidade das sementes. Piracicaba: FEALQ, 1987. 230p.

MILLER, M.R.; NORSWORTHY, J.K. Soybean sensitivity to florpyrauxifen-benzyl during reproductive growth and the impact on subsequent progeny. Weed Technology, v.32, n.2, p.135-140, 2018. https://dx.doi.org/10.1017/wet.2017.108

OLIVEIRA-JÚNIOR, R.S. Mecanismo de ação de herbicidas. In: OLIVEIRA-JÚNIOR, R.S.; CONSTANTIN, J.; INOUE, M.H. Biologia e manejo de plantas daninhas. Curitiba: Ed. Omnipax, 2011. p.141-192.

REN, Z.; WANG, X. SITIR1 is involved in crosstalk of phytohormones, regulates auxin-induced root growth and stimulates stenospermocarpic fruit formation in tomato. Plant Science, v.253, p.13-20, 2016. https://doi.org/10.1016/j.plantsci.2016.09.005

ROBINSON, A.P.; SIMPSON, D.M.; JOHNSON, W.G. Response of glyphosate-tolerant soybean yield components to dicamba exposure. Weed Science, v.61, n.4, p.526-536, 2013. https://dx.doi.org/10.1614/WS-D-12-00203.1

SHUAI, H.; MENG, Y.; LUO, X.; CHEN, F.; ZHOU, W.; DAI, Y.; QI, Y.; DU, J.; YANG, F.; LIU, J.; YANG, W.; SHU, K. Exogenous auxin represses soybean seed germination through decreasing the gibberellin/abscisic acid (GA/ABA) ratio. Scientific Reports, v.7, n.12620, 2017. https://dx.doi.org/10.1038/s41598-017-13093-w

SIADAT, S.A.; MOOSAVI, A.; ZADEH, M.S. Effect of seed priming on antioxidant activity and germination characteristics of maize seeds under different aging treatments. Research Journals of Seed Science, v.5, n.2, p.51-62, 2012. http://dx.doi.org/10.3923/ rjss.2012.51.62

SILVA, D.R.O.; SILVA, E.D.N.; AGUIAR, A.C.M.; NOVELLO, B.D.; SILVA, A.A.A.; BASSO, C.J. Drift of 2, 4-D and dicamba applied to soybean at vegetative and reproductive growth stage. Ciência Rural, v.48, n.8, 2018. http://dx.doi.org/10.1590/0103-8478cr20180179

SILVA, F.A.S.; AZEVEDO, C.A.V. Versão do programa computacional Assistat para o sistema operacional Windows. Revista Brasileira de Produtos Agroindustriais, v.4, n.1, p.71-78, 2002. http://www.deag.ufcg.edu.br/rbpa/rev41/Art410.pdf

SOLOMON, C.B.; BRADLEY, K.W. Influence of application timings and sublethal rates of synthetic auxin herbicides on soybean. Weed Technology, v.28, n.3, p.454-464, 2014. https://dx.doi.org/10.1614/WT-D-13-00145.1

THOMPSON, L.; EGLI, D.B. Evaluation of seedling progeny of soybeans treated with 2, 4-D, 2, 4-DB, and dicamba. Weed Science, v.21, n.2, p.141-144, 1973. https://www.jstor.org/stable/4042065

VANZOLINI, S.; ARAKI, C.A.S.; SILVA, A.C.T.M.; NAKAGAWA, J. Teste de comprimento de plântula na avaliação da qualidade fisiológica de sementes de soja. Revista Brasileira de Sementes, v.29, n.2, p.90-96, 2007. http://dx.doi.org/10.1590/S0101-31222007000200012

VIEIRA, R.D.; KRZYZANOWISKI, F.C. Teste de condutividade elétrica. In: KRZYZANOWISKI, F.C; VIEIRA, R.D; FRANÇA-NETO, J.B. (ed). Vigor de sementes: conceitos e testes. Londrina: ABRATES, 1999. p.1-26.

WAX, L.M.; KNUTH, L. A.; SLIFE, F. W. Response of soybeans to 2, 4-D, dicamba and picloram. Weed Science, v.17, n.3, p.388-393, 1969. https://www.jstor.org/stable/4041262

ZUCHI, J.; FRANÇA-NETO, J.B.; SEDIYAMA, C.S.; LACERDA-FILHO, A.F.; REIS, M.S. Physiological quality of dynamically cooled and stored soybean seeds. Journal of Seed Science, v.35, n.3, p.353-360, 2013. http://dx.doi.org/10.1590/S2317-15372013000300012 use, distribution, and reproduction in any medium, provided the original work is properly cited. 